\title{
TINGKAT KESUKAAN KONSUMEN PADA ATRIBUT BERAS PANDANWANGI MURNI CIANJUR
}

\author{
Oleh: \\ *Nurjaya \\ **Nenden Maulida
}

\begin{abstract}
ABSTRAK
Kabupaten Cianjur merupakan salah satu daerah penghasil padi terbesar di Jawa Barat. Salah satunya adalah beras Pandanwangi sebagai produk unggulannya. Beras pandanwangi memiliki atribut penting yaitu atribut butir utuh, murni, aroma dan memiliki tektur yang lembut. Penelitian ini dilakukan untuk 1). Mengetahui atribut beras Pandanwangi murni Cianjur yang dikenali konsumen, 2). Mengetahui tingkat kesukaan konsumen pada atribut beras Pandanwangi. Penelitian ini menggunakan metode analisis deskriptif. Selain dilakukan pengklasifikasian nilai skor rata-rata tanggapan responden ke kategori tidak kuat sampai sangat kuat, juga dilakukan proses perangkingan untuk mendapatkan tingkat kesukaan pada atribut beras Pandanwangi. Hasil penelitian menjawab tujuan penelitian sebagai berikut : 1). Konsumen mengenali semua atribut beras Pandanwangi meliputi aroma, kepulenan, tekstur lembut dan butir utuh. 2). Tingkat kesukaan konsumen terhadap atribut beras Pandanwangi adalah sangat kuat pada atribut aroma.
\end{abstract}

Kata kunci : aroma, tekstur lembut, murni, beras Pandanwangi, preferensi.

\begin{abstract}
Cianjur regency is one of the largest rice producing areas in West Java. One of the variety produces is local aromatic rice named as Pandanwangi rice famous because of its characterics. Pandanwangi rice has some important attributes, including whole grains attribute, its purity, aromatic smell and soft texture. This study was conducted for some purposes such as 1) to discover the purity attribute recognized by the consumers, 2) to assess the level of consumer preferences on Pandanwangi rice attribute. This research uses descriptive analysis method. In addition to the classification of the average score of the respondent responses to the category of not strong to very strong, also the ranking process was done to get the level of preferences on the attribute of Pandanwangi rice. The results of the research answer the following research objectives: 1). Consumers recognize all the attributes of Pandanwangi rice including aroma, soft texture, purity and whole grains. 2). The level of consumer preferences for the Pandanwangi rice attribute is very strong in the aroma attribute.
\end{abstract}

Keywords: aroma, soft texture, pure, Pandanwangi rice, preference.

*Dosen Fakultas Sains Terapan UNSUR

**Alumnus Fakultas Sains Terapan UNSUR

\section{PENDAHULUAN}

Pembangunan pertanian di Indonesia saat ini mempunyai peranan yang sangat penting bagi kehidupan masyarakat terutama usaha pertanian yang meliputi hortikultura, perkebunan, perternakan, serta perikanan. Pembangunan pertanian bertujuan untuk selalu memperbaiki mutu hidup dan kesejahteraan manusia terutama petani, baik perorangan maupun masyarakat pada umumnya (Mardikanto, 2013). Bahwa pembangunan pertanian merupakan bagian dari pembangunan nasional yang memiliki tujuan utama untuk meningkatkan kesejahteraan petani melalui peningkatan produksi. Dengan adanya hal tersebut diharapkan pendapatan petani dapat meningkat sehingga dapat memenuhi kebutuhan 
hidupnya baik untuk konsumsi maupan hal lainnya.

Sektor pertanian merupakan penyumbang terbesar pada Produk Domestik Regional Bruto (PDRB) Kabupaten Cianjur, ini terbukti dengan terkenalnya produksi beras Cianjur di seluruh Indonesia. Kabupaten Cianjur sudah sejak lama dikenal sebagai salah satu penghasil padi terbesar di Jawa Barat. Padi yang dihasilkan para petani di Kabupaten Cianjur sangat dikenal tidak hanya di wilayah Jawa Barat tetapi sudah diakui oleh masyarakat Indonesia secara menyeluruh. Meskipun banyak wilayah lain di Indonesia yang disebut lumbung padi, seperti Kabupaten Solok di Sumatera Barat, Minahasa di Sulawesi Selatan, namun tetap wilayah Kabupaten Cianjur terkesan yang paling terkenal dengan beras Pandanwangi sebagai produk unggulannya (Pemkab Cianjur, 2011).

Jawa Barat memiliki beberapa varietas padi unggul yang bisa menghasilkan beras kualitas premium. Salah satunya adalah beras Pandanwangi Cianjur. Beras Pandanwangi Cianjur (Aromatic rice) merupakan salah satu jenis beras kualitas premium dan komoditas unggulan Kabupaten Cianjur.

Menurut (BBPTP 2010), Keunggulan beras ini dapat dilihat dari segi penampilan fisik yang baik, rasa yang pulen dan aroma pandan yang menyenangkan (pleasant odour). Perbedaan aroma yang terdapat dalam beras Pandanwangi dengan beras yang tidak memiliki aroma khusus adalah dari kandungan alkohol (n-pentanol, 1oktan-3-ol, mentol dan estragol), aldehid dan keton ( n-pentanal, n-heptanal dan n-nonanal) yang lebih tinggi. Padi beraroma ini memiliki 15 kali lebih banyak 2-asetil-1 pirolina dibandingkan padi biasa (Suhendri 2013). Selain itu, rasa pulen yang dihasilkan dari kandungan amylase yang mencapai $24 \%$ ini membuat beras Pandanwangi banyak diminati oleh masyarakat meskipun harga lebih tinggi dari beras pada umumnya. Kebutuhan pasar yang tinggi itu tidak diimbangi dengan produksi yang tersedia di sentra produksi.

Produksi padi Pandanwangi mengalami penurunan setiap tahunnya. Selain karena merupakan tanaman yang memiliki indikasi geografis khusus, yaitu hanya dapat optimal ditanam di daerah tertentu, penurunan juga disebabkan oleh beberapa faktor. Salah satu faktor tersebut yaitu adanya serangan hama dan penyakit. Padi Pandanwangi rentan terhadap serangan penggerek batang dan wereng batang coklat biotipe 2 dan 3 (Disperta Cianjur 2012). Varietas unggul lokal ini ditanam di dataran sedang dengan ketinggian sekitar $700 \mathrm{~m}$ di atas permukaan laut, tinggi tanaman $150-170 \mathrm{~cm}$.

Padi Pandanwangi adalah salah satu jenis varietas padi bulu (javanica) yang tumbuh dan berkembang di Cianjur yang juga merupakan salah satu varietas lokal khas Cianjur yang berasnya sebagian besar dipasarkan dan dikonsumsi oleh masyarakat golongan menengah ke atas karena memiliki cita rasa yang khas seperti: rasa nasi yang enak, pulen, gurih dan beraroma khas daun pandan. Keunggulan Beras Pandanwangi Cianjur adalah kepulenan dan aroma khas wangi daun pandan. Berdasarkan penelitian yang telah dilakukan, komponen utama pembentuk aroma daun pandan pada Beras Pandanwangi Cianjur adalah komponen yang identik dengan penghasil aroma pada daun pandan, yaitu 2-acetyl-1-pyrolline. Buttery et al (1983), menyatakan bahwa komponen tersebut juga ditemukan pada analisis terhadap komponen volatil daun pandan (pandanus amaryllifolius).

Kekhasan yang dimiliki Pandanwangi tersebut membuat beras Pandanwangi diminati masyarakat menengah ke atas, baik sebagai oleholeh ataupun untuk konsumsi pribadi. Oleh karena itu, Dinas Pertanian Kabupaten Cianjur menetapkan padi Pandanwangi sebagai komoditas unggul utama hasil pertanian di samping tanaman palawija, sayuran, buahbuahan dan tanaman hias.

\section{Tujuan Penelitian}

Adapun tujuan penelitian ini adalah :

1. Untuk mengetahui atribut beras Pandanwangi murni Cianjur yang dikenali konsumen.

2. Untuk mengetahui tingkat kesukaan (preferensi) konsumen pada atribut beras Pandanwangi.

\section{TINJAUAN PUSTAKA}




\section{Atribut Produk}

Atribut produk adalah suatu komponen yang merupakan sifat-sifat produk yang menjamin agar produk tersebut dapat memenuhi kebutuhan dan keinginan yang diharapkan oleh pembeli. Atribut produk dapat berupa sesuatu yang berwujud (tangible) maupun sesuatu yang tidak berwujud (intangible). (Gitosudarmo, 2007). Atribut yang berwujud dapat berupa merek, kualitas produk, desain produk, label produk, kemasan dan sebagainya. Yang tidak berwujud seperti kesan atau image konsumen terhadap nama merek yang diberikan kepada produk tersebut. Setiap produk akan memiliki atribut yang berbeda dengan jenis produk yang lain.

\section{Karakteristik Pandanwangi}

Sifat Fisik beras Pandanwangi Cianjur memiliki ciri-ciri sebagai berikut : bentuk membulat, agak panjang, mempunyai bagian berkapur pada bagian perutnya yang ditunjukkan dengan warna putih. Bagian berkapur yang ditemukan pada Beras Pandanwangi Cianjur termasuk jenis white belly. Hasil pengukuran terhadap butiran gabah dan Beras Pandanwangi Cianjur menunjukkan bahwa Beras Pandanwangi Cianjur termasuk dalam kategori beras berukuran panjang (rata-rata $6.2 \mathrm{~mm}$ ) dan berbentuk agak bulat (rata-rata nisbah $\mathrm{p} / 1=$ 2.4).

Berdasarkan data kadar amilosa, nasi dan Beras Pandanwangi Cianjur (26.15\%) memiliki tekstur yang relatif lebih pera daripada IR64 (24,48) dan Gilirang (20.91\%). Di lain pihak nilai gel konsistensi Pandanwangi sebesar $47.5 \mathrm{~mm}$ (bertekstur lunak). Nampaknya kombinasi kadar amilosa yang tinggi dengan gel konsistensi yang rendah menjadikan varietas padi Pandanwangi memiliki tekstur nasi yang spesifik yaitu, pulen dan tidak cepat basi (Hamzah et all, 2003).

\section{Beras Pandanwangi Murni Cianjur}

Beras Pandanwangi memiliki ciri-ciri sebagai berikut : bentuk membulat, agak panjang, beraroma khas pandan, mempunyai bagian berkapur pada bagian perutnya yang ditunjukkan dengan warna putih. Bentuk Beras Pandanwangi Cianjur berbeda dengan kerabat terdekatnya yang diperoleh dari pemuliaan padi Pandanwangi melalui proses radiasi untuk mempercepat masa panen, yaitu padi Pandanputri. Padi Pandanputri juga telah dilepas sebagai varietas unggul melalui Surat Keputusan Menteri Pertanian No. 2366/Kpts/SR. 120/6/2010, tanggal 28 Juni 2010.

Menurut Natalia (2007), Hasil pengukuran terhadap butiran gabah dan Beras Pandanwangi Cianjur menunjukkan bahwa Beras Pandanwangi Cianjur termasuk dalam kategori beras berukuran panjang (rata-rata $6.2 \mathrm{~mm}$ ) dan berbentuk agak bulat (rata-rata nisbah $\mathrm{p} / 1=$ 2.4). Densitas Beras Pandanwangi Cianjur dalam 1 liter wadah adalah sebesar 863,2 gram. Persentase beras kepala, beras patah dan menir pada kadar air 14\% berturut-turut adalah sekitar 47,6\%, 17,0\% dan 36,6\%. Berdasarkan hasil pengukuran terhadap $300 \mathrm{~g}$ beras Pandanwangi giling yang dilakukan sebanyak 10 kali diketahui bahwa sudut curah sampel beras tersebut adalah sebesar 27,70. Beras Pandanwangi Cianjur juga mempunyai bagian berkapur pada bagian perut. Bagian berkapur yang ditemukan pada Beras Pandanwangi Cianjur termasuk jenis white belly.

Keunggulan Beras Pandanwangi Cianjur adalah kepulenan dan aroma khas wangi daun pandan. Berdasarkan penelitian yang telah dilakukan, komponen utama pembentuk aroma khas dari Pandanwangi Cianjur diduga karena adanya senyawa turunan asam amino fenil alanin yaitu 2-acetyl-1-pyrroline (Faras et al.,2014).

\section{Definisi Konsumen}

Menurut Dewi (2013), konsumen adalah seseorang yang menggunakan produk dan atau jasa yang dipasarkan. Sedangkan kepuasan konsumen adalah sejauh mana harapan para pembelian seorang konsumen dipenuhi atau bahkan dilebihi oleh sebuah produk. Jika harapan konsumen tersebut dipenuhi maka ia akan merasa puas, dan jika melebihi harapan konsumen, maka konsumen akan merasa senang.

\section{Perilaku konsumen}

Perilaku konsumen merupakan tindakan yang dilakukan oleh seseorang, kelompok maupun lembaga berdasarkan pada pengamatan 
dalam proses memilih, membeli, menggunakan dan membuang barang, jasa, ide dan pengalaman untuk memenuhi kebutuhan dan keinginannya. Konsumen memiliki sikap dan perilaku. Sikap konsumen adalah evaluasi menyeluruh yang dilakukan konsumen terhadap obyek fisik dan sosial. Yang dimaksud obyek fisik adalah produk, merek dan perusahaan. Konsumen menggabungkan beberapa pengetahuan, pengertian dan kepercayaan mengenai produk atau merek untuk membentuk evaluasi secara menyeluruh. Sementara obyek sosial adalah perilaku yang merupakan tindakan spesifik yang ditujukan terhadap beberapa tujuan. Perilaku seringkali terkait dengan situasi, lingkungan dan waktu. Pengetahuan konsumen yang diaktifkan disebut kepercayaan, yang mendasari sikap, norma subyektif dan intensi, dan pada akhirnya kepada perilaku (Bagram, Mohammad and Khan, S, 2012; Peter and Olson, 2013).

\section{Karakteristik Konsumen}

Karekteristik yang biasanya mempengaruhi konsumen dalam pengambilan keputusan pembelian adalah karakteristik budaya, sosial, pribadi dan psikologis (Kotler dan Armstrong, 2008).

\section{a. Faktor Budaya}

Kelas budaya, sub budaya dan sosial sangat mempengaruhi perilaku pembelian konsumen (Kotler dan Keller, 2009). Budaya didefinisiskan sebagai sejumlah nilai, kepercayaan dan kebiasaan yang digunakan untuk menunjukkan perilaku konsumen langsung dari kelompok masyarakat tertentu (Schiffman dan Kanuk, 2007).Menurut Kotler dan Armstrong (2008), budaya (culture) adalah penyebab keinginan dan perilaku seseorang yang paling dasar.budaya merupakan hasil kreativitas manusia dari generasi ke generasi berisikan nilai, norma, peraturan, adat, kebiasaan manusia yang bisa mempengaruhi perilaku kosumen dalam masyarakat.

b. Faktor Sosial

Menurut Kotler dan Armstrong (2008), faktor sosial ini bisa terdiri dari kelompok acuan, keluarga, serta peran dan status social. Strata sosial ada berdasarkan hirarki tertentu seperti pekerjaan, pendidikan, dan penghasilan.
Biasanya kelas sosial ini mengelompokkan orang yang sama berdasarkan kesamaan perilaku mereka dalam proses perekonomian mereka.

c. Faktor Pribadi

Menurut Suryani (2013), kepribadian juga dipandang sebagai karakteristik yang ada dalam diri individu yang melibatkan berbagai proses psikologis yang akan menentukan kecenderungan dan respon seseorang terhadap lingkungan. Faktor pribadi meliputi usia dan tahap dalam siklus hidup pembeli, pekerjaan dan keadaan ekonomi, kepribadian, konsep diri, serta gaya hidup dan nilai (Kotler dan Armstrong, 2008). Kepribadian adalah faktor dari dalam diri yang mempengaruhi seseorang dalam mengambil keputusan berupa usia, tahap siklus hidup, pekerjaan, keadaan ekonomi, dan gaya hidup.

d. Faktor Psikologis

Psikologis konsumen adalah salah satu cabang ilmu dari psikologis. Psikologis konsumen lebih mempelajari pada sikap yang dilakukan konsumen. Menurut Carlson et.al (1997), psikologis konsumen merupakan studi tentang motivasi, persepsi, pembelajaran kognisi dan perilaku pembelian individu di pasar dan penggunaan produk tersebut di rumah. Studi ini dapat dilihat baik dari sudut pandang penjual atau konsumen bahkan dapat juga dari sudut pandang keduanya dalam Ferrinadewi (2008).

Dalam menjatuh pilihan pada suatu produk pilihan konsumen dipengaruhi oleh faktor psikologis yaitu motivasi, persepsi, pembelajaran, kebutuhan dan sikap.

a. Motivasi dapat digambarkan sebagai suatu kekuatan yang mana individu didorong untuk melakukan suatu tindakan (Amirullah,2002).

b. Persepsi (perception) adalah proses dimana kita memilih, mengatur dan menerjemahkan masukan informasi untuk menciptakan gambaran dunia yang berarti (Kotler dan Keller, 2009).

c. Pembelajaran (learning) ini menggambarkan tentang perubahan dalam perilaku seseorang yang timbul dari pengalaman (Kotler dan Armstrong, 2008). 
d. Keyakinan adalah pemikiran deskriptif yang dimiliki seseorang tentang sesuatu (Kotler dan Armstrong, 2008).

e. Sikap (attitude) seseorang adalah predisposisi (keadaan mudah terpengaruh) untuk memberikan tanggapan terhadap rangsangan lingkungan, yang dapat memulai atau membimbing tingkah laku orang tersebut (Dharmmesta dan Handoko, 2012).

\section{Preferensi konsumen}

Preferensi konsumen merupakan suatu sikap konsumen terhadap satu pilihan merek produk yang terbentuk melalui evaluasi atas berbagai macam merek dalam berbagai pilihan yang tersedia. Kotler dan Keller (2009). Sedangkan menurut Frank (2011), preferensi adalah proses merengking seluruh hal yang dapat dikonsumsi dengan tujuan memperoleh preferensi atas suatu produk maupun jasa. Menurut Kotler dan Keller (2007), ada beberapa tahap yang akan dilalui oleh konsumen sehingga menggambarkan rasa kepuasannya terhadap suatu produk.

\section{Kerangka Konsep}

Padi Pandanwangi Cianjur merupakan jenis padi aromatik yang tergolong padi bulu (Javanica). Beras Pandanwangi memiliki atribut penting yang menjadi keunggulan beras Pandanwangi Cianjur adalah dari sifat fisik-kimia yaitu dari butir utuh, murni, aroma khas wangi daun pandan dan memiliki tekstur yang pulen. Keunggulan Beras Pandanwangi Cianjur adalah kepulenan dan aroma khas wangi daun pandan. Berdasarkan penelitian yang telah dilakukan, komponen utama pembentuk aroma daun pandan pada Beras Pandanwangi Cianjur adalah komponen yang identik dengan penghasil aroma pada daun pandan, yaitu 2-acetyl-1-pyrolline. Buttery et al (1983), menyatakan bahwa komponen tersebut juga ditemukan pada analisis terhadap komponen volatil daun pandan (pandanus amaryllifolius).

Kekhasan yang dimiliki beras Pandanwangi tersebut membuat beras Pandanwangi sangat diminati oleh masyarakat menengah keatas baik sebagai oleh-oleh maupun untuk konsumsi pribadi. Salah satu tujuan dari penelitian ini adalah menganalisis tingkat kesukaan konsumen pada atribut Pandanwangi murni Cianjur yaitu pada atribut butir utuh, kemurnian beras, aroma dan pulen. Untuk lebih jelas dalam penelitian ini penulis menggambarkan kerangka konsep seperti pada gambar 1 di bawah ini.

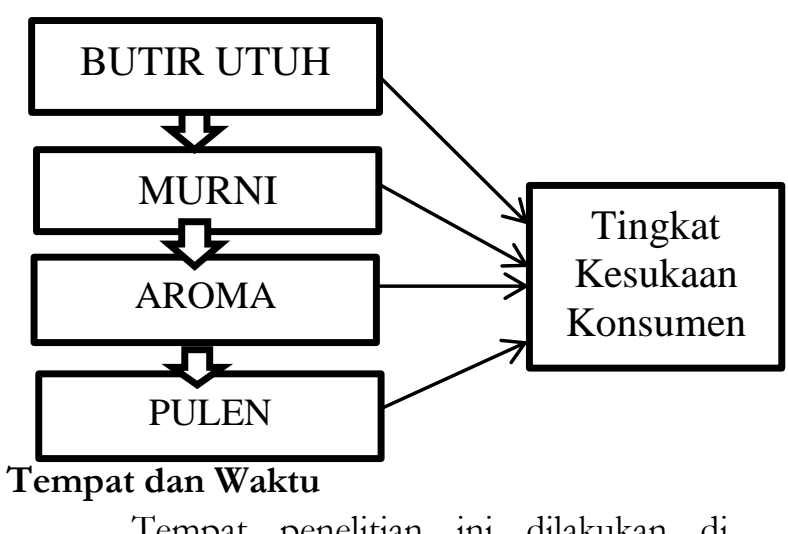

Kabupaten Cianjur di beberapa lokasi terutama di tempat-tempat yang mengkonsumsi beras Pandanwangi. Penelitian ini dilaksanakan mulai bulan Desember 2017 sampai dengan Bulan April 2018.

\section{Populasi, Sampel dan Teknik Sampling}

Menurut Sugiyono (2013), Populasi adalah keseluruhan subjek atau totalitas subjek penelitian yang dapat berupa; orang, benda, / suatu hal yang di dalamnya dapat diperoleh dan atau dapat memberikan informasi (data) penelitian. Populasi adalah wilayah generalisasi yang terdiri atas; obyek atau subyek yang mempunyai kuantitas dan karakteristik tertentu yang ditetapkan oleh peneliti untuk dipelajari dan kemudian ditarik kesimpulannya. Populasi dalam penelitian ini adalah konsumen beras Pandanwangi Cianjur di Kabupaten Cianjur yang sudah mengkonsumsi minimal setahun terakhir.

Menurut Sugiyono (2008), bahwa sampel merupakan bagian dari jumlah dan karakteristik yang dimiliki oleh populasi tersebut. Bila populasi besar, dan peneliti tidak mungkin mempelajari semua yang ada pada populasi, misalnya karena keterbatasan data, tenaga dan waktu, maka peneliti dapat menggunakan sampel yang diambil dari populasi itu. Apa yang 
dipelajari dari sampel itu, maka kesimpulannya akan dapat diberlakukan untuk populasi.

Sampel yang digunakan dalam penelitian ini diambil berdasarkan data yang dapat mewakili populasi secara keseluruhan (representatif). Oleh karena itu, sampel yang digunakan dalam penelitian ini adalah keseluruhan jumlah populasi yang menjadi subjek penelitian. Sebagaimana yang dikemukakan oleh Sugiyono (2011) bahwa : "jumlah anggota sampel yang diharapkan 100\% mewakili populasi adalah sama dengan jumlah anggota populasi itu sendiri”. Berdasarkan pendapat di atas, maka sampel dalam penelitian ini mengambil seluruh populasi untuk dijadikan sumber data. Sampel sebanyak 35 konsumen beras Pandanwangi murni Cianjur.

Karena populasi konsumen beras Pandanwangi tidak diketahui jumlahnya, maka dilakukan sampling dengan teknik non probability sampling adalah teknik pengambilan sampel yang tidak memberi peluang kesempatan yang sama bagi setiap unsur atau anggota populasi untuk dipilih melalui teknik sampling kuota. Menurut Sugiyono (2001) dalam Nasir (2017) , menyatakan bahwa sampling kuota adalah teknik untuk menentukan sampel dari populasi yang mempunyai ciri-ciri tertentu sampai jumlah kuota yang diinginkan. Sampel diambil dengan memberikan jatah dan quarum tertentu terhadap kelompok. Pengumpulan data dilakukan langsung pada unit sampling. Setelah kuota terpenuhi, pengumpulan data dihentikan. Sampel dalam penelitian ini adalah konsumen beras Pandanwangi Cianjur di Kabupaten Cianjur yang sudah mengkonsumsi minimal setahun terakhir.

\section{Definisi Operasi Variabel Penelitian}

Menurut Sugiyono (2012) dalam Diki Supriatna (2017), Variabel penelitian adalah suatu atribut atau sifat atau nilai dari orang, objek atau kegiatan yang mempunyai variasi tertentu yang ditetapkan oleh peneliti untuk dipelajari dan ditarik kesimpulannya. Sedangkan menurut Zikmund (2010), variabel adalah sesuatu yang bervariasi atau berubah dari satu contoh ke contoh lainnya. Variabel biasanya menunjukan perbedaan pada nilai, misalnya besaran, kekuatan, atau arah. Jenis variabel yang digunakan dalam penelitian yaitu variabel independen (bebas) dan variabel dependen (terikat).

Variabel bebas yang dilambangkan dengan $(\mathrm{X})$ adalah variabel yang mempengaruhi atau yang menjadi sebab perubahannya atau timbulnya variabel independen (bebas) dan variabel dependen (terikat) yang dilambangkan dengan (Y) adalah variabel yang dipengaruhi atau yang menjadi akibat, karena adanya variabel bebas (Sugiyono, 2014). Maka penulis akan menguraikan dalam bentuk tabel yang disajikan dalam tabel 1 berikut :

Tabel 1. Variabel Penelitian

\begin{tabular}{|c|c|c|c|}
\hline $\begin{array}{l}\text { Variabel } \\
\text { Penelitian }\end{array}$ & $\begin{array}{l}\text { Konsep } \\
\text { Variabel }\end{array}$ & Indikator & Skala \\
\hline $\begin{array}{l}\text { Butir Utuh } \\
\quad\left(\mathrm{X}_{1}\right)\end{array}$ & $\begin{array}{l}\text { Beras tidak seperti kebanyakan sereal } \\
\text { lainnya, dikonsumsi dalam bentuk butiran } \\
\text { utuh. Dengan demikian sifat fisik beras } \\
\text { seperti ukuran, bentuk, keseragaman, dan } \\
\text { kenampakan juga berperan penting dalam } \\
\text { hal mutu (Anonim 2003). Selanjutnya, } \\
\text { karena beras mengalami proses } \\
\text { penyosohan, maka sifat penting yang } \\
\text { menyangkut karakter fisik tersebut } \\
\text { ditentukan terutama oleh butiran endosperm } \\
\text { beras. }\end{array}$ & $\begin{array}{l}\text { 1. Butir beras utuh } \\
\text { 2. Bentuk butir beras } \\
\text { seragam }\end{array}$ & Ordinal \\
\hline $\begin{array}{l}\text { Murni } \\
\left(\mathrm{X}_{2}\right)\end{array}$ & $\begin{array}{l}\text { Kemurnian beras adalah kemurnian yang } \\
\text { berhubungan dengan keberadaan benda } \\
\text { asing seperti batu, tanah, jerami, sekam, } \\
\text { dll selain padi (Yulianingsih, 2012). } \\
\text { konsumen akan menyukai beras yang }\end{array}$ & $\begin{array}{l}\text { 1. Bersih dari kotoran dan } \\
\text { benda asing } \\
\text { 2. Tidak tercampur varietas } \\
\text { lain }\end{array}$ & \\
\hline
\end{tabular}




\begin{tabular}{|c|c|c|c|}
\hline $\begin{array}{l}\text { Variabel } \\
\text { Penelitian }\end{array}$ & $\begin{array}{l}\text { Konsep } \\
\text { Variabel }\end{array}$ & Indikator & Skala \\
\hline & $\begin{array}{l}\text { bersih, tidak tampak adanya benda asing } \\
\text { dan disebut beras murni sesuai varietas. }\end{array}$ & & Ordinal \\
\hline $\begin{array}{l}\text { Aroma } \\
\left(\mathrm{X}_{3}\right)\end{array}$ & $\begin{array}{l}\text { Aroma khas dari Pandanwangi Cianjur } \\
\text { diduga karena adanya senyawa turunan } \\
\text { asam amino fenil alanin yaitu 2-acetyl-1- } \\
\text { pyrroline (Faras et al., } \\
\text { 2014). }\end{array}$ & $\begin{array}{l}\text { 1. Aroma khas wangi beras } \\
\text { 2. Aroma khas wangi nasi }\end{array}$ & Ordinal \\
\hline $\begin{array}{c}\text { Pulen } \\
\left(\mathrm{X}_{4}\right)\end{array}$ & $\begin{array}{l}\text { Kombinasi kadar amilosa yang tinggi } \\
\text { dengan gel konsistensi yang rendah } \\
\text { menjadikan varietas padi Pandanwangi } \\
\text { memiliki tekstur nasi yang spesifik yaitu, } \\
\text { pulen dan tidak cepat basi (Hamzah et all, } \\
\text { 2003). }\end{array}$ & 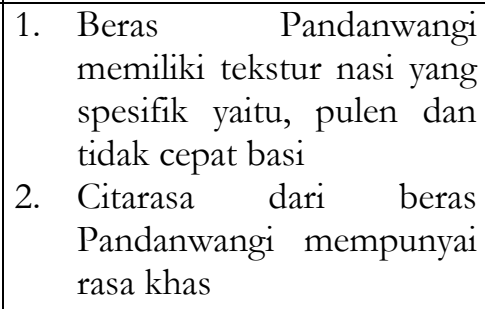 & Ordinal \\
\hline $\begin{array}{l}\text { Tingkat } \\
\text { Kesukaan } \\
\text { (Preferensi) } \\
\text { konsumen } \\
\quad \text { (Y) }\end{array}$ & $\begin{array}{l}\text { Preferensi konsumen merupakan suatu } \\
\text { sikap konsumen terhadap satu pilihan } \\
\text { merek produk yang terbentuk melalui } \\
\text { evaluasi atas berbagai macam merek } \\
\text { dalam berbagai pilihan yang tersedia. } \\
\text { Kotler dan Keller, (2009:181). }\end{array}$ & \begin{tabular}{|llr} 
1. & Lebih & menyukai \\
& $\begin{array}{l}\text { Pandanwangi } \\
\text { aroma khasnya }\end{array}$ & karena \\
2. & Lebih & menyukai \\
& Pandanwangi & karena \\
& butirnya utuh & \\
3. & Lebih & menyukai \\
& Pandanwangi & karena \\
& kemurniannya & \\
4. & Lebih & menyukai \\
& Pandanwangi & karena \\
& kepulenannya &
\end{tabular} & Ordinal \\
\hline
\end{tabular}

\section{Sumber dan Jenis Data}

Sumber dan jenis data yang digunakan dalam penelitian ini adalah data primer dan sekunder.

\section{Metode Analisis Data}

Analisis data adalah proses mencari dan menyusun secara sistematis data yang diperoleh dari hasil wawancara, catatan lapang, dan bahanbahan lain, sehingga dapat mudah dipahami, dan temuannya dapat diinformasikan kepada orang lain (Sugiyono, 2014).

Pengertian deskriptif menurut Sugiyono (2017), sebagai berikut: “Analisis deskriptif adalah statistik yang digunakan untuk menganalisis data dengan cara mendeskripsikan atau menggambarkan data yang telah terkumpul sebagaimana adanya tanpa bermaksud membuat kesimpulan yang berlaku untuk umum atau generalisasi."

Analisis deskriptif digunakan untuk mendapatkan gambaran tentang karakteristik responden. Berisi tentang bahasan secara deskriptif mengenai jawaban yang diberikan responden pada kuesioner. Analisis deskriptif dilakukan terhadap data responden yaitu jenis kelamin, usia, dan asal daerah responden. Analisis disusun berdasarkan jawaban responden dari kuesioner yang telah diajukan. Analisis deskriptif ini diterangkan dalam bentuk persentase dan disajikan dalam bentuk tabel. Pada penelitian ini analisis deskriptif digunakan untuk menganalisis tingkat kesukaan (preferensi) konsumen pada beras Pandanwangi.

Analisis deskriptif dilakukan untuk mengetahui fenomena variabel dengan menghitung nilai rata-rata jawaban responden. Nilai rata-rata responden dimasukkan ke dalam kelas interval, dimana rumus yang digunakan menurut Sudjana (2008) dalam Nasir (2017) adalah : 
Interval kelas $=$

nilai tertinggi-nilai terendah

jumlah kelas

Keterangan : $\quad$ nilai tertinggi $=5$

nilai terendah $=1$

jumlah kelas $=5$

Interval nilai $=5-1 /$ jumlah kelas $=4$ $-5=0,8$

Dari rumus tersebut diperoleh besarnya kelas interval adalah 0,8 .

\section{Penskoran Nilai Rata-rata Tanggapan Responden}

Untuk menentukan penskoran nilai rata-rata tanggapan responden. Data yang terhitung yaitu skor nilai dibagi jumlah responden hasil yang diperoleh di bandingkan dengan kategori nilai interval yaitu : 1). Tidak kuat, 2). Kurang kuat, 3). Cukup kuat, 4). Kuat, 5). Sangat kuat. berikut:

Kategori nilai interval yaitu sebagai

\section{Tabel 2 Kategori Nilai Interval}

\begin{tabular}{cc}
\hline Nilai Interval & Kategori \\
\hline $1-1,8$ & tidak kuat \\
$1,81-2,6$ & kurang kuat \\
$2,61-3,4$ & cukup kuat \\
$3,41-4,2$ & Kuat \\
$4,21-5$ & sangat kuat \\
\hline
\end{tabular}

\section{Perangkingan Nilai Skor Rata-rata}

Untuk menentukan perangkingan nilai skor rata-rata, rangking ditentukan dengan cara mengurutkan nilai skor responden dari nilai tertinggi sampai nilai terendah.

\section{HASIL DAN PEMBAHASAN}

\section{Karakteristik Responden}

Responden dalam penelitian ini adalah konsumen beras Pandanwangi yang mengkonsumsi beras Pandanwangi minimal 1 tahun terakhir. Jumlah keseluruhan responden dalam penelitian ini berjumlah 35 orang. Karakteristik responden yang dimasukkan dalam penelitian ini yaitu jenis kelamin, usia, alamat, status pernikahan, tingkat pendidikan, pendapatan, dan lama mengkonsumsi beras Pandanwangi. Karakteristik responden diperlukan dalam penelitian ini karena karakteristik yang berbeda-beda dapat mempengaruhi penilaian responden.

Sebagian besar konsumen beras Pandanwangi di dominasi oleh wanita yaitu sebanyak 25 orang dari 35 orang yang dijadikan sebagai responden atau sekitar (71\%), sedangkan pria berjumlah 10 orang atau sekitar (29\%). Dengan demikian, perempuan pada umumnya lebih berperan dalam urusan belanja rumah tangga dibandingkan laki-laki. Perempuan juga memiliki peran yang besar dalam proses pengambilan keputusan pembelian kebutuhan sehari-hari, termasuk dalam mengonsumsi beras.

Karakteristik responden berdasarkan usia didominasi oleh kelompok yang sudah cukup umur yaitu antara umur 42 - 50 tahun sebesar (43\%) lebih banyak dibandingan dengan kelompok lainnya yaitu sebesar $12 \%$ dan $11 \%$ berumur antara 54 - 60 dan 61 - 70\%, sebesar 17 $\%$ oleh responden yang berumur 24 - 30 dan 31 - 40 tahun. Dapat disimpulkan bahwa beras Pandanwangi juga banyak diminati oleh konsumen yang berusia 24 - 30 dan 31 - 40 tahun. Karena responden yang berusia $24-30$ dan 31 - 40 adalah usia yang sudah bisa membedakan antara rasa, aroma dan tekstur makanan.

Karakteristik responden berdasarkan asal daerah yang terbanyak yaitu dari Kecamatan Warungkondang dengan jumlah 13 orang atau sekitar 37\%. Keadaan ini terjadi karena salah satu kecamatan yang menjadi sektor pertanian yang berpotensi untuk ditanami padi Pandanwangi adalah salah satunya Kecamatan Warungkondang. Kecamatan Warungkondang adalah salah satu daerah yang menghasilkan padi Pandanwangi terbanyak di kabupaten Cianjur. Oleh karena itu, masyarakat yang ada di Kecamatan Warungkondang lebih mudah untuk mendapatkan atau membeli beras Pandanwangi, selain membeli masyarakat juga banyak yang mengkonsumsi dan menyukai beras Pandanwangi yang menjadi khas Cianjur ini. 
Berdasarkan kuesioner yang dibagikan pada 35 responden, diperoleh data mengenai status pernikahan responden. Dalam penelitian ini didominasi oleh responden yang sudah menikah. Responden yang telah menikah berjumlah 33 orang atau sekitar 94\% sedangkan responden yang masih lajang atau belum menikah berjumlah 2 orang atau sekitar $6 \%$.

Karakteristik responden berdasarkan tingkat pendidikan dalam penelitian ini yang paling banyak yaitu di tingkat pendidikan sarjana (S1) sebanyak 20 orang atau sekitar 57\%, sedangkan responden dengan jenjang pendidikan SMA yaitu berjumlah 13 orang atau sekitar 37\% dan responden dengan jenjang pendidikan SLTP berjumlah 2 orang atau sekitar $6 \%$. Dapat dijelaskan bahwa konsumen dengan pendidikan yang tinggi akan mempengaruhi proses keputusan pembelian. Dengan pendidikan yang semakin tinggi, konsumen akan lebih cerdas dalam memilih produk yang dibeli seperti memilih membeli beras karena dengan tingkat pendidikan yang dimiliki, mereka lebih sadar terhadap mutu dan keamanan beras yang mereka konsumsi.

Dari kuesioner penelitian diperoleh hasil bahwa responden dengan tingkat pendapatan rata-rata perbulan yang dimiliki oleh konsumen beras Pandanwangi lebih banyak didominasi sekitar 10 orang yang menghasilkan pendapatan $<$ Rp.3.000.000,00 dan 10 orang yang menghasilkan pendapatan >Rp.3.000.000,00 5.000.000,00 Persentase pendapatan terbesar yaitu sekitar >Rp.5.000.000,00 berjumlah 5 orang, responden yang menghasilkan pendapatan Rp.3.000.000,00 sebanyak 3 orang dan yang lainnya menghasilkan pendapatan perbulan tidak menentu sebanyak 7 orang karena mereka bekerja sebagai pengusaha dan petani. Dalam hal ini dapat dilihat pada Tabel 4.5 mengenai persentase pendapatan rata-rata perbulan yang diperoleh oleh para responden beras Pandanwangi. Hal ini menunjukkan bahwa rata-rata responden beras Pandanwangi adalah golongan masyarakat menengah ke atas.

Karakteristik responden berdasarkan lama mengkonsumsi beras Pandanwangi kurang dari 1 tahun yaitu berjumlah 8 orang atau sekitar $23 \%$. Responden yang mengkonsumsi lebih dari 1 tahun yaitu berjumlah 8 orang atau sekitar $23 \%$. Responden yang mengkonsumsi selama 2 tahun berjumlah 7 orang sedangkan responden yang paling banyak yaitu responden yang mengkonsumsi beras Pandanwangi tidak setiap bulan tetapi hanya sekali-kali pernah mengkonsumsi 3 sampai 4 kali beras Pandanwangi. Dapat dijelaskan bahwa konsumen yang mengkonsumsi beras Pandanwangi tidak setiap hari mengkonsumsi beras Pandanwangi tetapi hanya sekali-kali karena beras Pandanwangi mempunyai harga yang tinggi sehingga tidak setiap bulan konsumen membeli.

\section{ANALISIS HASIL PENELITIAN}

\section{Penskoran Nilai Rata-rata Berdasarkan Kategori}

1) Hasil Pengukuran Variabel Butir Utuh

Tabel 3 hasil Nilai Variabel Butir Utuh

\begin{tabular}{clcccc}
\hline No & \multicolumn{1}{c}{ Variabel Butir Utuh } & Rata-rata & Nilai Interval & Kategori \\
\hline 1 & $\begin{array}{l}\text { Butir beras yang utuh itulah } \\
\text { harapan konsumen }\end{array}$ & 4,31 & $4,21-5$ & Sangat kuat \\
2 & $\begin{array}{l}\text { Butir beras Pandanwangi utuh } \\
\text { sehingga konsumen suka }\end{array}$ & 4,14 & $4,21-5$ & Sangat kuat \\
3 & $\begin{array}{l}\text { Bentuk butir beras Pandanwangi } \\
\text { sama persis ukurannya (seragam) }\end{array}$ & 4,08 & $3,41-4,2$ & Kuat \\
& $\begin{array}{l}\text { sehingga konsumen suka } \\
4\end{array}$ & $\begin{array}{l}\text { Butir beras Pandanwangi yang } \\
\text { seragam dapat dikenali dari } \\
\text { bentuknya yang sama persis }\end{array}$ & 4,17 & $4,21-5$ & Sangat kuat \\
\end{tabular}

Sumber : Data primer, 2018 
Berdasarkan perhitungan dari rata-rata indikator dikemukakan bahwa perhitungan hasil jawaban responden pada sub variabel butir utuh didapat nilai rata-rata sebesar 4,31 termasuk dalam kategori sangat kuat. Dalam hal ini konsumen menyukai butir beras Pandanwangi yang utuh. Hal ini dapat dipahami mengingat sebagian besar konsumen beras Pandanwangi adalah masyarakat menengah ke atas yang sangat memperhatikan mutu dan kualitas dari produk yang mereka beli. Bentuk fisik beras dianggap penting oleh konsumen karena berkaitan dengan kebersihan, warna, dan kesegaran butir beras tersebut. Apabila bentuk fisik beras terlihat tidak bagus, kotor, kutuan, dan pecah-pecah maka konsumen akan enggan untuk membelinya. Sehingga dalam penelitian ini konsumen beras Pandanwangi menyukai butir beras Pandanwangi utuh.

2) Hasil Pengukuran Variabel Murni

Tabel 4 Hasil Nilai Variabel Murni

\begin{tabular}{clccc}
\hline No & \multicolumn{1}{c}{ Variabel Murni } & Rata-rata & Nilai Interval & Kategori \\
\hline 1 & $\begin{array}{l}\text { Saya jarang menemukan benda } \\
\text { lain/kotoran di kemasan beras } \\
\text { Pandanwangi }\end{array}$ & 3,88 & $3,41-4,2$ & Kuat \\
2 & $\begin{array}{l}\text { Saya tidak pernah menemukan } \\
\text { benda lain/kotoran di kemasan } \\
\text { beras berlabel Pandanwangi } \\
\text { tidak ditemukan benda asing } \\
\text { (kotoran, gabah) dalam } \\
\text { kemasan beras berlabel } \\
\begin{array}{l}\text { Pandanwangi } \\
4\end{array}\end{array}$ & 3,85 & $3,41-4,2$ & Kuat \\
$\begin{array}{l}\text { Tidak ditemukan ada beras } \\
\text { Varietas lain di kemasan beras } \\
\text { berlabel Pandanwangi }\end{array}$ & 3,8 & $3,41-4,2$ & Kuat \\
\hline
\end{tabular}

Dari tabel di atas hasil pengukuran variabel kemurnian berdasarkan perhitungan dari setiap indikator dikemukakan bahwa perhitungan hasil jawaban responden didapat nilai rata-rata sebesar 3,94 termasuk dalam kategori kuat (3,41 - 4,2). Merujuk pada indikator tidak ditemukan benda asing (kotoran, gabah) dalam kemasan beras berlabel Pandanwangi. Tanggapan konsumen menunjukkan bahwa tingkat kesukaan konsumen pada kemurnian beras adalah kuat.

3) Hasil Pengukuran Variabel Aroma

Tabel 5 Hasil Nilai Variabel Aroma

\begin{tabular}{clccc}
\hline No & \multicolumn{1}{c}{ Variabel Aroma } & Rata-rata & Nilai Interval & Kategori \\
\hline 1 & $\begin{array}{l}\text { Beras Pandanwangi mempunyai } \\
\text { aroma khas yang disukai oleh } \\
\text { konsumen }\end{array}$ & 4,74 & $4,21-5$ & Sangat kuat \\
2 & $\begin{array}{l}\text { Beras Pandanwangi } \\
\text { mengeluarkan aroma yang khas }\end{array}$ & 4,71 & $4,21-5$ & Sangat kuat \\
3 & $\begin{array}{l}\text { Aroma harus beras Pandanwangi } \\
\text { mempunyai ciri yang khas }\end{array}$ & 4,68 & $4,21-5$ & Sangat kuat
\end{tabular}

4 Aroma beras Pandanwangi

$\begin{array}{lllll}\text { tercium pada } & \text { saat } & 4,6 & 4,21-5 & \text { Sangat kuat }\end{array}$

Data Primer, 2018.

Dari tabel di atas hasil pengukuran variabel aroma berdasarkan perhitungan dari rata-rata indikator dikemukakan bahwa 
perhitungan hasil jawaban responden pada sub variabel aroma didapat nilai rata-rata sebesar 4,74 termasuk dalam kategori sangat kuat. Merujuk pada indikator beras Pandanwangi mempunyai aroma khas yang disukai oleh konsumen. Dengan kategori yang sangat kuat, hal ini membuktikan bahwa beras Pandanwangi memang mempunyai aroma yang khas yaitu wangi khas beras yang disukai oleh konsumen. Sebagian besar responden menyatakan setuju bahwa beras Pandanwangi yang dibeli memang memiliki karakteristik beraroma wangi khas. Konsumen juga sangat setuju dengan aroma beras Pandanwangi tercium pada saat dimasak.

4) Hasil Pengukuran Variabel Pulen

Tabel 6 Hasil Nilai Variabel Pulen

\begin{tabular}{|c|c|c|c|c|}
\hline No & Variabel Pulen & Rata-rata & Nilai Interval & Kategori \\
\hline 1 & $\begin{array}{l}\text { Beras Pandanwangi mempunyai } \\
\text { tekstur yang lembut (pulen) yang } \\
\text { disukai oleh konsumen }\end{array}$ & 4,68 & $4,21-5$ & Sangat kuat \\
\hline 2 & $\begin{array}{l}\text { Beras Pandanwangi dikenal } \\
\text { karena kepulenannya }\end{array}$ & 4,65 & $4,21-5$ & Sangat kuat \\
\hline 3 & $\begin{array}{l}\text { Beras Pandanwangi murni lebih } \\
\text { pulen daripada Pandanwangi } \\
\text { yang dicampur dengan beras jenis } \\
\text { lainnya }\end{array}$ & 4,31 & $4,21-5$ & Sangat kuat \\
\hline 4 & $\begin{array}{l}\text { Murni tidaknya beras } \\
\text { Pandanwangi dapat dikenali dari } \\
\text { kepulenannya }\end{array}$ & 3,85 & $3,41-4,2$ & Kuat \\
\hline 5 & $\begin{array}{l}\text { Nasi dari beras Pandanwangi } \\
\text { terasa pulen }\end{array}$ & 4,54 & $4,21-5$ & Sangat kuat \\
\hline
\end{tabular}

Sumber : Data primer, 2018

Dari tabel di atas hasil pengukuran variabel kepulenan berdasarkan perhitungan dari setiap indikator dikemukakan bahwa perhitungan hasil jawaban responden didapat nilai rata-rata sebesar 4,68 termasuk dalam kategori sangat kuat $(4,21$ - 5). Hal ini menunjukkan bahwa alasan konsumen mengkonsumsi beras Pandanwangi secara terus menerus yaitu karena beras Pandanwangi selain mempunyai aroma yang khas juga mempunyai tekstur yang lembut (pulen) yang disukai oleh konsumen.

5) Hasil Pengukuran Variabel Tingkat Kesukaan Konsumen

Tabel 7 Hail Nilai Variabel Tingkat Kesukaan Konsumen

\begin{tabular}{|c|c|c|c|c|}
\hline No & $\begin{array}{c}\text { Variabel Tingkat Kesukaan } \\
\text { Konsumen }\end{array}$ & Rata-rata & Nilai Interval & Kategori \\
\hline 1 & $\begin{array}{lcr}\text { Saya lebih } & \text { menyukai } & \text { beras } \\
\text { Pandanwangi } & \text { karena } & \text { aroma } \\
\text { khasnya } & & \end{array}$ & 4,71 & $4,21-5$ & Sangat kuat \\
\hline 2 & $\begin{array}{l}\text { Saya lebih menyukai beras } \\
\text { Pandanwangi karena butirnya } \\
\text { utuh }\end{array}$ & 4,2 & $3,41-4,2$ & Kuat \\
\hline 3 & $\begin{array}{lr}\text { Saya lebih } & \text { menyukai } \\
\text { Pandanwangi } & \text { karena } \\
\text { kemurniannya } & \end{array}$ & 4,48 & $4,21-5$ & Sangat kuat \\
\hline 4 & $\begin{array}{lrr}\text { Saya lebih menyukai } & \text { beras } \\
\text { Pandanwangi } & & \text { karena } \\
\text { kepulenannya } & & \end{array}$ & 4,45 & $4,21-5$ & Sangat kuat \\
\hline
\end{tabular}


beras Pandanwangi memiliki nilai rata-rata tertinggi yaitu sebesar 4,71 termasuk dalam kategori sangat kuat. Merujuk pada indikator saya lebih menyukai beras Pandanwangi karena aroma khasnya. Hal ini menunjukkan bahwa yang paling menentukan tingkat kesukaan konsumen terhadap beras Pandanwangi yaitu konsumen lebih menyukai beras Pandanwangi karena mempunyai aroma yang khas yaitu wangi khas beras yang berbeda dengan beras jenis lainnya.

\section{Perangkingan Skor Nilai Rata-rata}

Dari butir pernyataan diperoleh skor nilai rata-rata tanggapan responden. Untuk melihat tingkat kesukaan konsumen terhadap atribut beras Pandanwangi, dilakukan perangkingan skor rata-rata tanggapan konsumen sebagai berikut :

Tabel 8 Hasil Perangkingan Skor Nilai Rata-rata Tanggapan Responden

\begin{tabular}{|c|c|c|c|c|}
\hline No & Butir Pernyataan & Rata-rata & Nilai Interval & Kategori \\
\hline 1 & $\begin{array}{l}\text { Beras Pandanwangi mempunyai } \\
\text { aroma khas yang disukai oleh } \\
\text { konsumen }\end{array}$ & 4,74 & $4,21-5$ & Sangat Kuat \\
\hline 2 & $\begin{array}{l}\text { Beras Pandanwangi } \\
\text { mengeluarkan aroma yang khas }\end{array}$ & 4,71 & $4,21-5$ & Sangat Kuat \\
\hline 3 & $\begin{array}{l}\text { Saya lebih menyukai beras } \\
\text { Pandanwangi karena aroma } \\
\text { khasnya }\end{array}$ & 4,71 & $4,21-5$ & Sangat Kuat \\
\hline 4 & $\begin{array}{l}\text { Aroma harus beras Pandanwangi } \\
\text { mempunyai ciri yang khas }\end{array}$ & 4,68 & $4,21-5$ & Sangat Kuat \\
\hline 5 & $\begin{array}{l}\text { Beras Pandanwangi mempunyai } \\
\text { tekstur yang lembut (pulen) yang } \\
\text { disukai oleh konsumen }\end{array}$ & 4,68 & $4,21-5$ & Sangat Kuat \\
\hline 6 & $\begin{array}{l}\text { Beras Pandanwangi dikenal } \\
\text { karena kepulenannya }\end{array}$ & 4,65 & $4,21-5$ & Sangat Kuat \\
\hline 7 & $\begin{array}{l}\text { Aroma beras Pandanwangi } \\
\text { tercium pada saat } \\
\text { ditanak/dimasak }\end{array}$ & 4,6 & $4,21-5$ & Sangat Kuat \\
\hline 8 & $\begin{array}{l}\text { Nasi dari beras Pandanwangi } \\
\text { terasa pulen }\end{array}$ & 4,54 & $4,21-5$ & Sangat Kuat \\
\hline 9 & $\begin{array}{lr}\text { Saya lebih } & \text { menyukai } \\
\text { Pandanwangi } & \text { karena } \\
\text { kemurniannya } & \end{array}$ & 4,48 & $4,21-5$ & Sangat Kuat \\
\hline 10 & $\begin{array}{lr}\text { Saya lebih menyukai beras } \\
\text { Pandanwangi } & \text { karena } \\
\text { kepulenannya } & \end{array}$ & 4,45 & $4,21-5$ & Sangat Kuat \\
\hline 11 & $\begin{array}{l}\text { Beras Pandanwangi murni lebih } \\
\text { pulen daripada Pandanwangi } \\
\text { yang dicampur dengan beras } \\
\text { jenis lainnya }\end{array}$ & 4,4 & $4,21-5$ & Sangat Kuat \\
\hline 12 & $\begin{array}{l}\text { Butir beras yang utuh itulah } \\
\text { harapan konsumen }\end{array}$ & 4,31 & $4,21-5$ & Sangat Kuat \\
\hline 13 & $\begin{array}{l}\text { Butir beras Pandanwangi yang } \\
\text { seragam dapat dikenali dari } \\
\text { bentuknya yang sama persis }\end{array}$ & 4,17 & $4,21-5$ & Sangat Kuat \\
\hline
\end{tabular}




\begin{tabular}{|c|c|c|c|c|}
\hline No & Butir Pernyataan & Rata-rata & Nilai Interval & Kategori \\
\hline 14 & $\begin{array}{l}\text { Butir beras Pandanwangi utuh } \\
\text { sehingga konsumen suka }\end{array}$ & 4,14 & $4,21-5$ & Sangat Ku \\
\hline 15 & $\begin{array}{l}\text { Bentuk butir beras Pandanwangi } \\
\text { sama persis ukurannya (seragam) } \\
\text { sehingga konsumen suka }\end{array}$ & 4,08 & $3,41-4,2$ & Kuat \\
\hline 16 & $\begin{array}{l}\text { Saya lebih menyukai beras } \\
\text { Pandanwangi karena butirnya } \\
\text { utuh }\end{array}$ & 4,2 & $3,41-4,2$ & Kuat \\
\hline 17 & $\begin{array}{l}\text { tidak ditemukan benda asing } \\
\text { (kotoran, gabah) dalam kemasan } \\
\text { beras berlabel Pandanwangi }\end{array}$ & 3,94 & $3,41-4,2$ & Kuat \\
\hline 18 & $\begin{array}{l}\text { Saya jarang menemukan benda } \\
\text { lain/kotoran di kemasan beras } \\
\text { Pandanwangi }\end{array}$ & 3,88 & $3,41-4,2$ & Kuat \\
\hline 19 & $\begin{array}{l}\text { Saya tidak pernah menemukan } \\
\text { benda lain/kotoran di kemasan } \\
\text { beras berlabel Pandanwangi }\end{array}$ & 3,85 & $3,41-4,2$ & Kuat \\
\hline 20 & $\begin{array}{l}\text { Murni tidaknya beras } \\
\text { Pandanwangi dapat dikenali dari } \\
\text { kepulenannya }\end{array}$ & 3,85 & $3,41-4,2$ & Kuat \\
\hline 21 & $\begin{array}{l}\text { Tidak ditemukan ada beras } \\
\text { Varietas lain di kemasan beras } \\
\text { berlabel Pandanwangi }\end{array}$ & 3,8 & $3,41-4,2$ & Kuat \\
\hline
\end{tabular}

Sumber : Data Primer, 2018

Dari hasil tabel di atas menunjukkan bahwa variabel aroma yang memiliki nilai ratarata tertinggi yaitu sebesar 4,74 termasuk dalam kategori sangat kuat. Dengan demikian bahwa dari hasil perangkingan skor nilai rata-rata tanggapan responden didapatkan nilai yang paling tinggi yaitu sebesar 4,74 termasuk dalam kategori sangat kuat, Didapat nilai rata-rata sebesar 4,6 terhadap indikator beras Pandanwangi tercium pada saat ditanak/dimasak. Oleh karena itu, konsumen banyak yang menjawab hal tersebut membuktikan bahwa yang paling menentukan tingkat kesukaan konsumen terhadap atribut beras Pandanwangi yaitu variabel aroma dikarenakan beras Pandanwangi sangat disenangi konsumen kelas menengah ke atas karena memiliki cita rasa yang khas seperti : aroma wangi khas, pulen dan murni yang berbeda dengan beras jenis lainnya sehingga beras Pandanwangi ini sangat diminati oleh masyarakat Cianjur.

Hasil jawaban responden terendah yaitu pada atribut kemurnian. Didapat nilai rata-rata sebesar 3,8 termasuk dalam kategori kuat. Dengan demikian dapat dijelaskan bahwa masih banyak konsumen yang masih menemukan ada kotoran di kemasan beras berlabel Pandanwangi.

Dari hasil perangkingan hasil skor nilai rata-rata dari butir pernyataan diperoleh skor nilai rata-rata tanggapan responden dari nilai tertinggi hingga nilai terendah yaitu didapat nilai tertinggi dari variabel aroma dan nilai terendah dari variabel kemurnian. Dapat disimpulkan 
bahwa yang menentukan tingkat kesukaan konsumen terhadap atribut beras Pandanwangi yaitu dari aroma khas beras Pandanwangi.

\section{KESIMPULAN DAN SARAN}

\section{Kesimpulan}

Dari hasil penelitian dapat disimpulkan bahwa :

1) Berdasarkan hasil penelitian terhadap atribut beras Pandanwangi murni Cianjur yang dikenali konsumen dapat disimpulkan bahwa konsumen mengenali semua atribut beras Pandanwangi dari mulai atribut aroma, kepulenan, butir utuh dan kemurnian.

2) Berdasarkan hasil penelitian dan perangkingan sejumlah atribut beras Pandanwangi murni Cianjur dapat disimpulkan bahwa tingkat kesukaan konsumen pada atribut beras Pandanwangi termasuk kategori sangat kuat sebesar 4,74 (skala 1-5) terhadap atribut aroma. Hal tersebut membuktikan bahwa yang paling menentukan tingkat kesukaan konsumen terhadap atribut beras Pandanwangi yaitu variabel aroma dikarenakan beras Pandanwangi memiliki aroma wangi khas daun pandan yang berbeda dengan beras jenis lainnya sehingga beras Pandanwangi ini

\section{SARAN} sangat diminati oleh masyarakat Cianjur.

Saran dalam penelitian ini adalah sebagai berikut

1) Bagi Petani Pelestari Beras Pandanwangi: Setelah mengetahui tingkat kesukaan konsumen terhadap atribut beras Pandanwangi diharapkan untuk petani agar dapat mengembangkan dan mempertahankan keunggulan yang dimiliki beras Pandanwangi murni Cianjur, khususnya tentang atribut aroma wangi khas beras yang disukai oleh konsumen.

2) Bagi Pemerintah Kabupaten Cianjur: Pemerintah kabupaten Cianjur perlu mendukung sosialisasi beras Pandanwangi Cianjur yang murni kepada masyarakat agar masyarakat
Cianjur lebih mengenal beras

Pandanwangi sebagai kearifan lokalnya.

\section{DAFTAR PUSTAKA}

Buttery, RG, Ling, LC, dan Juliano, BO. 1983.

Identification of Rice Aroma

Compound 2-acety-1-pyrroline in Pandan

Leaves. J. Agriculture Food Chem. 31: 823-826.

Bergman, C., Ming-Hsuan Chen, J. Delgado, and N. Gipson. 2006. Kernel form: rice grain quality. USDA-ARS-Rice Research Unit Rice Quality Program. http://beaumont.tamu.edu/eLibrary/St udiRiceContest/2006/Rice Grain Quality. March 2006.

Dharmmesta, Basu Swastha dan T. Hani Handoko. 2012. Manajemen Pemasaran. Edisi Pertama Cetakan Keliama. Yogyakarta: BPFE.

Dewi. 2013. Definisi Konsumen. http://eprints.polsri.ac.id/666/3/BAB\%20II.pd $\underline{f}$

Ferrinadewi Erna. 2008. Merek \& Psikologi Konsumen. Edisi Pertama. Yogyakarta: Graha Ilmu.

Gitosudarmo. 2007. Manajemen Pemasaran, BPFE.

Yogyakarta.

Hamzah Basah, Mamat Rachmat, Supardi, Hardedi, Jumadi, Tuteng Jauhari, Tansyah Abadi dan Iyus Rusliana. 2003. Laporan Akbir Pemurniaan dan Standarisasi Padi Sawah Varietas Pandanwangi. Dinas Pertanian Kabupaten Cianjur Bekerjasama dengan UPTD Balai Pengawasan dan Sertifikasi benih Tanaman Pangan dan Hortikultura Provinsi Jawa Barat 2003.

Mardikanto, T. 2013. Penyuluban Pembangunan Pertanian. Sebelas Maret University Press. Surakarta.

Menteri Pertanian No. 2366/Kpts/SR. 
120/6/2010, tanggal 28 Juni 2010.

Natalia. 2007. Karakterisasi Beras Pandanwangi dan Pengaruh Jenis Kemasan Terhadap Stabilitas Mutu Selama Penyimpanan. Fakultas Teknologi Pertanian Institut Pertanian Bogor.

Pemerintah Kabupaten Cianjur. 2011. Tanaman Pangan dan Hortikultura. Cianjur: Pemkab Cianjur 2011.
Sugiyono. 2017.2 Deskriptif. http://repository.unpas.ac.id/27868/5/BAB\%2 OIII.pdf

Sugiyono. 2012. Metode Penelitian Bisnis. Bandung : Alfabeta.

Sugiyono. 2011. Metode Penelitian Kuantitatif, Kualitatif dan R\&OD. Bandung: Alfabeta.

Kotler, Philip \& Keller, L. Kevin. 2009. Manajemen Pemasaran. Edisi 13, Jilid 1. Jakarta: Pearson Education, Inc.

Kotler dan Amstrong. 2008. Prinsip-prinsip Pemasaran. Jilid 1, Penerbit Erlangga. Jakarta.

Suryani. 2013. Perilaku Konsumen di Era Internet.

Edisi Pertama. Cetakan Pertama.

Yogyakarta: Graha Ilmu. 